\begin{tabular}{ll}
\hline & Kastamonu Eğitim Dergisi \\
Kastamonu Education Journal & Kaburu Tarihi/Received: 24.01 .2019 \\
Kefdergi.kastamonu.edu.tr & Kabul Tarihi/Accepted: 24.06 .2019 \\
\hline
\end{tabular}

\title{
Tarihsel Seyir İçinde Eğitim Yönetiminin Bilimleşme Süreci
}

\section{The Development of Educational Administration as a Scientific Field in Historical Course}

\author{
Öz \\ Gökhan SAVAŞ ${ }^{1}$
}

Bu çalışmanın amacı tarihsel süreç içinde eğitim yönetimi alanının yaşadığı bilimleşme sürecinin incelenmesidir. Çalışmada ilk olarak eğitim yönetiminin bir bilim olup olmadığına yönelik alanyazında yer alan tartışmalara yer verilmiştir. Eğitim yönetiminin bilim olma kriterleri çerçevesinde nasıl tanımlandığı ortaya konmuştur. Daha sonra eğitim yönetimi alanının ABD'de temelleri atılan bilimleşme süreci 19. yüzyılın sonlarından başlanarak inceleme konusu edilmiştir. Son olarak eğitim yönetiminin bilimleşme sürecinde yaşadığı evrilmenin Türkiye'deki yansımaları ele alınmıştır. Yapılan incelemeler 1900'lü yıllara kadar bilimsel bir niteliğe kavuşamayan eğitim yönetimi alanının felsefi tartışmalardan beslendiği, 1900 'lü yılların ilk çeyreğinde Taylor tarafından ortaya atılan bilimsel yönetimin etkisi altında kaldığı, işletme ve ekonomi alanlarına bağımlı olarak geliştiği; 1950'li yıllarda ABD'de ortaya çıkan teori hareketi ile kendine özgü sınırlarını çizmeye ve bağımsız bir bilim olarak ortaya çıkmaya başladığı, 20. yüzyılın son çeyreğinde eğitimde mantıksal pozitivist yaklaşımın eleştiriye uğradığı ve öznel-yorumsamacı yönde bir paradigmatik dönüşüm yaşadığı görülmüştür. Mevcut çalışmada, eğitim yönetimi alanı gelişme sürecinde çeşitli bilim dallarından etkilense de bir bilim olarak inceleme konusu edilmeye başlandığı andan itibaren bağımsız bir alan olmak için çaba gösterdiği sonucuna ulaşılmıştır.

Anahtar Kelimeler: eğitim, eğitim yönetimi, bilimleşme

\section{Abstract}

The purpose of this study is to examine the development of educational administration as a scientific field in historical course. In the study, firstly discussions about whether educational administration is a scientific discipline and its justifications were presented. Definitons of educational administration were given within the scope of scientificness criteria. Subsequently, scientization process of educational administration rooted in USA was examined beginning from the end of $19^{\text {th }}$ century. Finally, reflections of the transformation in educational administration in Turkey was discussed. Analysis revealed that until 1900 s the field of educational administration that could not gain a scientific quality was enriched with philosophical debates, influenced by Taylorism and developed under the disciplines of business and economy, began to draw its own line and emerge as a dependent science with theory movement in 1950s, underwent a paradigmatic change towards subjectivist-interpretivist approach as a result of criticism of rational positivism. In the present study, it was concluded that the field of educational administration has struggled to become an independent discipline since it was handled as a scientific research area.

Keywords: education, educational administration, scientization

\footnotetext{
${ }^{1}$ Şehit Burak Kapucuoğlu illkokulu/Ortaokulu, Milli Eğitim Bakanlığı, Kastamonu, Türkiye, https://orcid.org/0000-0003-0690-8733

Atıf / Citation: Savaş, G. (2020). Tarihsel Seyir Iç̧inde Eğitim Yönetiminin Bilimleşme Süreci. Kastamonu Education Journal, 28(1), 253-266. doi:10.24106/kefdergi.3553
} 


\section{Extended Abstract}

Introduction: Educational administration plays a key role in operating educational functions and using human and physical resources effectively (Aslanargun, 2007). In this respect, educational administration have become a highly interested issue in recent years. With the increasing pace of global economy, governments have become aware of the importance of qualified labor force that could be raised by effective school leaders. (Bush, 2007). Moreover, government policies related to developing educational administration are important in that they are used as a standart in the changeable context of schools and play an important role in school improvement (Gorard, 2005).

Educational administration as a field of study has a rich epistemological and ontological ground (Eacott \& Evers, 2015). Since the emergence of educational administration as an academic discipline, scientists tried to understand the nature of the field, examined the dominant views and paradigms and focused on the intellectual history of the field. (Oplatka 2009). Educational administration has undergone a rich intellectual process from the attempts to form a positivism based science of management to Greenfield rooted criticism in 1970s and a range of theoritical alternatives developed in 1980s (Evers \& Lakomski, 2001). However, emergence of educational administration as an occupation happened in the late $19^{\text {th }}$ century. In the early $20^{\text {th }}$ century educational administration was entreated in scientific studies and spreaded across England and other countries respectively. In this period, the pursuit of productivity on the agenda of educational administration influenced aducation as well and the struggle to make education more productive encouraged several educationalists to participate in administrator training programmes. In the following years this resulted in institutionalisation and scientization of educational administration (Oplatka, 2008). Educational administration that began to develop in $19^{\text {th }}$ century have tried to create a unique identity and treated as a independent field of study since 1950s. The field was influenced by theoritical developments in various fields and managed to develop its own theories (Beycioğlu \& Dönmez, 2006; Özdemir, 2017). The factors such as accountability, globalisation, student-based theories, contemporary leadership approaches and cultural diversity emerged towards the late of $20^{\text {th }}$ century caused contextual transformations in educational administration (Balcl, 2011). With the new thories, educational sytstem changed both in content and management. Educational services became a public realm with the handling of educational administration as a scientific discipline and the increase in the number of schools due to economical, social and political developments (Özdemir, 2011). The terms of positivism and logic was opposed by the alternatives such as culture, language and context and this resulted in "the war of paradigms" (Şişman, 1998). Internalisation and globalisation based improvements also caused changes in educational administration. Approaches towards education, administration and leadership changed as well (Samier, 2017). There is a controversy over whether educational administration is a dependent scientific field or a branch of science of management. This conflicts have been going on since the dawn of the field and it seems to go on in the future (Eacott, 2017). This process that educational administration has undergone was defined as "intellectual turmoil. Mapping the past is a guide for today. There are several lessons to be taken from past for today and the future (Aldrich, 2014). Historical research is needed in the field of educational administration because it is vital to see the reflections of the intellectual debates for developing any field.

Purpose: The purpose of this study is to examine the scientization process of educational administration in historical course. In the study, firstly discussions about whether educational administration is a scientific discipline and its justifications were presented. Definitons of educational administration were given within the scope of scientificness criteria. Subsequently, scientization process of educational administration rooted in USA was examined beginning from the end of $19^{\text {th }}$ century. Finally, reflections of the transformation in educational administration in Turkey was discussed.

Results and discussion: In the historical course, it was heavily discussed whether educational administration has been a science or not. In spite of the accelaration in educational administration recent years, the field has been criticized in that it does not have its own theoritical knowledge base and accumulation, has its roots from another fields, it gets stuck between theory and practice, it is positivism based, it is poor in educational side and does not have a theoritical consensus in scientific circle. In the related literature the main ground of the discussions is eucational administration is not an independent discipline because it developed under the influence of business management, public administration, sociology and psychology. However, especially thanks to the theory movement emerged in the United States in 1950s, educational administraion began to draw its own boundaries and turned out to be an independent disclipline. In this respect, it was seen as an independent field of study having professorships and degrees in universities, unique research subjects and scientific journal and publications. As a result of study it was revealed that until $1900 \mathrm{~s}$ the field of educational administration that could not gain a scientific quality was enriched with philosophical debates, influenced by Taylorism and developed under the disciplines of business and economy, began to draw its own line and emerge as a dependent science with theory movement in 1950s, underwent a paradigmatic change towards subjectivist-interpretivist approach as a result of criticism of rational positivism. In the present study, it was concluded that the field of educational administration has struggled to become an independent discipline since it was handled as a scientific research area.

It is thought that theoritical studies are needed to contribute to the knowledge accumulation of educational administration. It is usual to expect that studies in educational administration contribute to the educational system and schools of a country. However, these studies should also move educational administration forward and contribute to its scientization. Furthermore, academicians of educational administration should have concerns over the present state and future of the field and try to reach a consensus in this direction. 


\section{Giriş}

Eğitim yönetimi, eğitimin işlevlerinin gerçekleştirilmesinde ve eğitim örgütlerinde mevcut bulunan insani ve maddi unsurların etkili bir biçimde kullanılmasında önemli rol oynamaktadır (Aslanargun, 2007). Bu bağlamda eğitim yönetimi alanına karşı ilgi son yıllarda büyük ölçüde artmıştır (Örücü ve Şimşek, 2011). Özellikle 21. yüzyılın başlangııından itibaren etkili liderliğin öğrenme çıktılarını etkileyerek okullarda fark yarattığını öne süren yaygın inancın etkisiyle eğitim yönetimi alanına karşı yoğun bir ilgi görülmektedir. Küresel ekonominin hız kazanmasıyla birlikte devletler en önemli varlıklarının yetenekli iş gücü olduğunun ve bunu sağlamanın da eğitim sisteminde önemli rol oynayan etkili okul yöneticileri sayesinde gerçekleşebileceğinin farkına varmışlardır (Bush, 2007). Ayrıca eğitim yönetimi alanı, eğitimin geliştirilmesine yönelik devlet politikalarının oluşturulması için önemlidir çünkü okulların değişken bağlamında bir standart olarak kullanılmakta ve okul gelişimi için önemli rol oynamaktadır (Gorard, 2005).

Bilimsel bir çalışma alanı olarak eğitim yönetimi, zengin bir epistemolojik ve ontolojik temele sahiptir (Eacott ve Evers, 2015). Eğitim yönetimi alanının akademik bir alan olarak doğuşundan itibaren bilim insanları alanın doğasını anlamaya çalışmışar, alandaki hâkim görüş ve paradigmaları incelemişler ve alanın entelektüel tarihini mercek altına almışlardır (Oplatka, 2009). 1950'li yıllarda mantıksal temelde bir yönetim bilimi oluşturma çabalarından 1970'li yıllarda Greenfield kaynaklı eleştirilere ve 1980 'lerden itibaren geliştiren bir dizi kuramsal alternatife kadar zengin bir entelektüel süreç yaşamıştır (Evers ve Lakomski, 2001). Bununla birlikte eğitim yöneticiliğinin profesyonel bir meslek olarak ortaya çıkışı 19. yüzyılın sonlarına rastlamaktadır. 20. yüzyılın başlarında ise eğitim yönetimi ABD'de bulunan üniversitelerde bilimsel çalışmalara konu edilmiş ve akabinde başta İngiltere olmak üzere diğer ülkelere yayılmıştır. Bu dönemde yönetim alanında gündemin önemli bir kısmını oluşturan verimlilik arayışı eğitimi de etkisi altına almış ve eğitimde verimliliği sağlama çabası birçok eğitimciyi, yönetici yetiştirme programlarına katılmaya teşvik etmiştir. Bu durum sonraki yıllarda eğitim yönetiminin kurumsallaşmasında ve akademik bir disiplin haline gelmesinde önemli rol oynamıştır (Oplatka, 2008). 20. yüzyılın ilk yarısında gelişmeye başlayan eğitim yönetimi 1950'lerden itibaren kendine özgü bir kimlik yaratma çabası içine girmiş ve bağımsız bir alan olarak ele alınmıştır. Bu dönemde eğitim yönetimi çeşitli alanlarda meydana gelen kuramsal gelişmelerin etkisi altında kalmış ve kendine özgü kuramlar oluşturabilmiştir (Beycioğlu ve Dönmez, 2006; Özdemir, 2017). 1960'lar boyunca eğitim yönetimi alanında çalışan bilim insanları önemli araştırma problemleri belirlemeye, sosyal bilimlerden alınan kuramları uygulamaya ve daha büyük oranda bilimsel araştırma yöntemlerinden faydalanma çabası içinde olmuşlardır. 1970'lerden itibaren alanda yapılan çalışmalar öğretimden ve okul bağlamından kopuk olması nedeniyle eleştirilmiştir. Bu dönemde etkili okul hareketiyle birlikte çalışmalara konu edilen öğretimsel liderlik yaklaşımı eğitim yönetimi araştırmalarında bir paradigm değişikliğine neden olmuştur. 1990'lar boyunca okulun yeniden yapılandırılması, liderlik, okul yöneticiliğinin profesyonelleşmesi, ve dönüşümcü liderlik konularına ilişkin yeni eğilimler eğitim politikaları ve araştırmalarının yönünü değiştirmiştir (Hallinger ve Kovačević, 2019). Ayrıca, 20. yüzyılın sonlarına doğru ortaya çıkan hesap verebilirlik, küreselleşme, öğrenci odaklıık, çağdaş liderlik yaklaşımları ve kültürel farkılıılar gibi unsurlar eğitim yönetimi alanında bağlamsal dönüşümlere neden olmuştur (Balcı, 2011).

Eğitim yönetiminin bilimsel bir disiplin olarak ele alınmasında; yirminci yüzyılda ortaya çıkan ekonomik, sosyal ve siyasi gelişmeler ile birlikte okul sayısının artması ve eğitim hizmetinin kamusal bir alan haline gelmesi önemli rol oynamıştır (Özdemir, 2011). Şişman (1998) bilimde özellikle de sosyal bilimler alanında bilgisel ve yöntemsel temelde yaşanan yoğun gelişmeler ile birlikte pozitivizme ve rasyonalizme karşı sübjektiflik, kültür, dil ve bağlam gibi kavramların alternatif olarak sunulduğunu ve bu durumun eğitim yönetimini de etkileyen bir "paradigmalar savaşına" yol açtığını ifade etmiştir. Turan (2004) ise sosyal bilimlerdeki gelişmelerin etkisiyle eğitim yönetiminde kuramsal bağlamda bazı paradigma değişimlerinin yaşandığını ifade etmiştir. Benzer biçimde Waite (2002) eğitim yönetimi alanında yapılan araştırmaların derin farklılıklar nedeniyle birbirinden ayrıldığını ve bazı paradigmatik farklılıkların araştırmacılar arasında tartışmalara yol açtığını belirtmiştir. Ayrıca küreselleşme ve uluslararasılaşmadan kaynaklanan değişimler de eğitim yönetiminde ve eğitim yönetimi alanının temelini oluşturan disiplinlerde dönüşüme neden olmuştur. Eğitim, yönetim ve liderliğe ilişkin yaklaşımlar da buna paralel olarak değişmiştir (Samier, 2017).

Geçmişin bir haritasını çıkarmak, günümüzde izlenecek yollara ilişkin bir rehber niteliğindedir. Eğitimsel konulara ilişkin geçmişteki uygulamalardan hem günümüz hem de gelecek için çıkarılabilecek dersler bulunmaktadır (Aldrich, 2014). Oplatka (2009) eğitim yönetimi alanında tarihsel incelemeye ihtiyaç duyulduğunu çünkü entelektüel tartışmaların yansımalarını görmenin herhangi bir alanın geliştirilmesi ve iyileştirilmesi için önemli olduğunu ifade etmiştir. Bu bağlamda mevcut araştırmanın amacı, tarihsel süreç içinde eğitim yönetimi alanının yaşadığını bilimleşme sürecinin derinlemesine incelenmesidir. Araştırma kapsamında eğitim yönetiminin doğuşundan bağımsız bir bilim haline gelişine ve günümüze kadar yaşadığı değişimler ele alınmıştır. Tarihsel dönem içerisinde alanı etkileyen gelişmeler, disiplinler, paradigmalar ve bilim insanları kavramsal bir çerçeve içerisinde sunulmuştur. Mevcut çalışmanın 
eğitim yönetimi alanında çalışan araştırmacıların çalışmalarına yön vereceği ve uygulama sahasında görev yapan eğitim yöneticilerinin alana ilişkin bilgi birikimlerine katkıda bulunacağı düşünülmektedir.

\section{Kavramsal Çerçeve}

\section{Eğitim Yönetiminin Tanımı}

Eğitim yönetimi alanı farklı bilim insanları tarafından bilim, sanat, politika, ahlaki felsefe, uygulama, tiyatro, sembolik etkileşimci başarı, problem çözme ve ideolojik kontrol gibi kavramlar çerçevesinde tanımlanmıştır (Anderson ve Gringberg, 1998). Bates (1983) eğitim yönetimini alandaki çeşitli gruplar arasındaki farklı görüşleri temsil eden birçok fikir ve uygulamayı kapsayan "şemsiye" bir kavram olarak nitelemiş, bilgiyi ve toplumu şekillendiren önemli bir insan faaliyeti olduğunu vurgulamıştır. English (2002) eğitim yönetimin uygulama ve araştırma boyutları olan bilimsel bir çalışma alanı olarak tanımlamıştır. Can (2018) eğitim yönetiminin tanımını "toplumun eğitim gereksinimini karşılamak üzere kurulan eğitim örgütünü önceden belirlenen amaçlarına göre işletme, değerlendirme ve geliştirme süreci" olarak yapmıştır. Özdemir (2018) eğitim yönetimini "eğitimdeki yönetsel olguları inceleyen bilim dalı" olarak tanımlayarak eğitim yönetiminin eğitim örgütlerinin elinde bulunan maddi kaynakları ve insan unsurunu etkili bir biçimde kullanarak eğitim hizmetlerinin gerçekleştirilmesini amaçladığını ifade etmiştir. Bush (2007) eğitim yönetimi ve eğitim liderliği kavramlarının genellikle birbirinin yerine kullanıldığını ve genel olarak her iki kavramın da temel olarak eğitimin amaçlarının gerçekleştirilmesine odaklandığını ifade etmiştir. Amadi-Eric (2008) ise eğitim yönetiminin okullarda eğitim ve öğretimi daha etkili ve işlevesel hale getirmek için insan kaynaklarının ve materyallerin bir araya getirilmesi olarak tanımlamıştır. Eğitim yönetimi araştırmacılar tarafından farklı yönlerden ele alınsa da yapılan tanımlardan eğitim yönetiminin yönetim biliminin eğitim alanında ve eğitim kurumlarında uygulanması olarak algılandığı yönünde bir çıkarım yapılabilir. Genel yönetim tanımlarında ele alından örgüt amaçları eğitim yönetimi bağlamında eğitim örgütlerinin amaçları olarak değerlendirilmektedir. Eğitim yönetiminin merkezi ve sınırları bulunmaktadır. Eğitim yönetimi alanı, sorunlarının belirlenmesini ve çözüm yollarının aranmasını sağlayan "entelektüel bakış açısı" sunmaktadır (English, 2001). Eğitim yönetimi alanını tamamen kapsayan tek bir kuram bulunmamaktadır. Bu durum küçük ilkokullardan büyük üniversitelere kadar sıralanan eğitim kurumlarının çeşitliliğini yansıtmaktadır. Aynı zamanda okullardaki farklı yaklaşım ve çözümler gerektiren sorunlar da bu çeşitliliğin bir nedeni olabilir. Hepsinin ötesinde eğitim yönetiminde hâkim bir kuramın olmayışı eğitim ve sosyal bilimlerin çok yönlü yapısının doğal bir sonucudur. Bu bağlamda, Bush (2006) eğitim yönetimindeki kuramlarının üç ana özelliğe sahip olduğunu belirtmektedir:

1- Eğitim yönetimi kuramları eğitim kurumları ve bu kurumlarda görev yapan bireylerin inanç ve değerlerini yansıtması bakımından normatif bir yapıya sahiptir.

2- Eğitim yönetimi kuramları eğitim kurumlarındaki belirli özellikle vurgulaması açısından seçicidir. Çünkü okullar tek bir boyutla analiz edilemeyecek kadar karmaşık yapıya sahiptir.

3- Eğitim yönetimi kuramları eğitim kurumlarındaki uygulamaların gözlemine dayanır ya da bu uygulamalar tarafından şekillendirilir.

\section{Bilimsel Bir Alan Olarak Eğitim Yönetimi}

Eğitim yönetiminin ayrı bir alan mı yoksa yönetim biliminin bir dalı mı olduğuna ilişkin tartışmalar bulunmaktadır. Eğitim yönetiminde bilgi üretimine ilişkin bu tartışmalar alanın doğuşundan itibaren süregelmiştir (Eacott, 2017) ve gelecekte de devam edecek gibi görünmektedir (Fitzgerald ve Gunter, 2008). Griffiths (1979) eğitim yönetimi alanının yaşamış olduğu durumu "entelektüel karmaşa" olarak tanımlamıştır. Bates (1983) eğitim yönetiminin akademik dünyada hiçbir zaman yüksek statüde görülen bir araştırma alanı olmadığını ifade ederek bunun nedenlerini kuramsal meseleler üzerinde fikir birliği olmaması, araştırma metodolojisinin yeterli olmaması ve alanın politik doğası olarak sıralamıştır. Benzer bir biçimde Fitz (1999) alanın kendi amaç ve kimliğini yeniden oluşturma ya da entelektüel olarak yenilenme çabası içinde olduğunu ve küçük bir güven krizi yaşadığını iddia etmiştir. Özdemir (2017) eğitim yönetiminin kapsamı ve içeriğine yönelik bu tartışmaların varlığını "epistemik bunalım" olarak nitelemiştir. Eğitim yönetimi farklı ve çoğunlukla çatışan epistemolojik tartışmaların süregeldiği bir çalışma alanıdır. Bilgi temeli olarak heterojen bir yapıya sahip olması eleştiri alsa da bu görüş farklılıkları alana zenginlik katmakta ve yeni sınırlar çizmektedir (Park, 2015).

Son yıllarda eğitim yönetimine ilişkin konuların alanının akademik çalışma alanı olarak büyük ilgi görmesine rağmen alanın kendine özgü bilgi birikimi ve ampirik araştırma temeli olmadığına dair görüşler öne sürülmektedir (Heck ve Hallinger, 2005). Bush'a göre (1999) eğitim yönetimi farklı bakış açıları tarafından çevrelenen çoğulcu bir yapıya sahiptir 
ve alanın doğasına ilişkin fikir birliği bulunmamaktadır. Ancak eğitim yönetimi alanı diğer alanlardan da etkilenmekle birlikte temel olarak eğitimin amaçlarına odaklanması bakımından farklılık göstermektedir. Hallinger ve Chen'e (2015) göre eğitim yönetiminin öncelikle uygulamalı bir bilimdir; bu nedenle alanın yönetim, psikoloji ve sosyoloji gibi alanlara kuramsal katkısı sınırıdır. Eğitim yönetimi alanı bilime kuramsal katkılarından ziyade, eğitim örgütlerine politika oluşturma ve uygulama alanı sağlamaya yönelik etkililiği açısından değerlendirilmelidir. Farklı bir bakış açısıyla Thrupp ve Wilmott (2003), Eğitim yönetimi alanında yapılan yayınlarda son yıllarda önemli bir artış görüldügünü ancak Eğitim yönetimi alanyazınında yönetim kavramının eğitimden daha fazla ön plana çıktığını ve Eğitim yönetimi alanında üretilen yayınların eğitimsel yönünün daha kuvvetli olması gerektiğini vurgulamışlardır. Maxcy (2001) günümüzde eğitim yönetiminin bir bilim olarak fazla ilgi odağı olmadığını; liderlik, standartlar ve performans yönetimi kavramlarının daha çok tartışıldığını ifade etmiştir. Benzer bir biçimde Özdemir (2017), eğitim yönetimi alanında çalışanların davranış bilimleri, örgüt teorisi ve yönetim gibi çeşitli alanların etkisi altında kalarak asıl amacı olan eğitim olgusunu ihmal ettiğini belirtmiştir. Bates (2013) ise eğitim yönetimi alanında önde gelen çalışmalarda eğitime ilişkin çalışmaların yetersizliğine dikkat çekerek alanın pozitivist bilimlerin kopyası olmaktan kurtulması gerektiğini ifade etmiştir. Öte yandan Paige ve Mastenhauser (1999) eğitim yönetimi alanında yöneticiler için gerekli olan zengin bir alanyazın bulunmadığını ifade ederek bu durumun nedenini alandaki yazarların pozitivizme karşı olmalarına bağlamıştır. Genel olarak eğitim yönetiminde bilgi temeli ve teori oluşturma çabaları rasyonel ve ampirik yöntemlerin kullanıldığı gerekçesiyle eleştiriye uğramış, bu yaklaşımların uygulamada işe koşulamayacağı eleştirilerin temel dayanağı olmuştur (Kochan, 2002).

Alanda yapılan çalışmalar incelendiğinde genel olarak eğitim yönetiminin kuram ve uygulama olarak ikiye ayrıldığı söylenebilir. Uygulamaya dönük çalışmaların sayısının kuramsal çalışmalara göre daha fazla olduğu görülmektedir. Ancak bu ayrım pozitivizm karşıtı tartışmalardan daha yoğun bir hale gelmiş ve eğitim yönetimi alanına zarar vermiştir. Eğitim yönetimi alanı "güçlü teori" ve "en iyi uygulama" arasında kalmıştır (Park, 2015). Erickson (1979) eğitim yönetiminde sürekli değişen fikirlerin kavramsal bir birliği engellediğini ve alanda bütünlük sağlayacak genel olarak kabul edilmiş bir paradigma olmadığını belirtmiştir. Benzer biçimde Bates (1983) eğitim yönetimi alanında uygulamaların, kuramların açıklayıcı işlevi olmadan yeteri kadar anlaşılamayacağını iddia eden kuramcılar ve soyut kuramların yönetsel işlerin doğasına aykırı olduğunu ifade eden uygulayıcılar arasında ikilem olduğunu ifade etmiştir. Eğitim yönetiminde kabul gören genel bir paradigma olmamasının sebepleri alanın örgütsel koşullar, eğitim politikası, eğitim ekonomisi ve sosyalleşme gibi değişken konulara odaklanması, birbirinde kopuk ve kuramsal olarak verimsiz araştırmaların olması ve araştırmaların belirli konulara odaklanarak farklı çalışmaları göz ardı etmesi olarak görülmektedir. Eğitim yönetimi alanını etkileyen bu faktörlerin belirlenmesinin gerekliliğine yönelik alanda bir fikir birliği olduğu ifade edilmektedir. Daha bütüncül kuramlar ve nitelikli araştırmalarla eğitim yönetimi alanındaki sorunların çözülebileceği öne sürülmüştür (Bates, 1982). Benzer bir biçimde Özdemir (2013) de eğitimin sosyal bir sistem olmasından dolayı işletme alanında üretilen kuramların etkisi altında olmasının sakıncalarını belirterek alana özgü kuramlar geliştirmenin gerekliliğini vurgulamıştır.

Eğitim yönetimi alanı sosyal bilimler ailesinde yer almaktadır. Ayrıca sosyal bilimlerin diğer alanlarıyla da ilişkilidir. Eğitim yönetiminin ilişkili olduğu alanlar işletme, kamu yönetimi, psikoloji, sosyoloji, siyaset bilimi ve hukuktur. Alan kavramı Fitz (1999) tarafından özel ilgi alanı, kuralları ve öncelikleri olan ve birbirlerine indirgenemeyen bilimsel inceleme alanı olarak tanımlanmıştır. Yazara göre alanlar birer çatışma yeridir çünkü savunucuları hangi bilgi ve uygulamaların meşru olacağına ve hangi bilgi ve uygulamalara yatırım yapacaklarına karar verme çabası içindedirler. Ayrıca her alanın savunucusu kendi sınırlarını korumaya çalışır. Yazar, eğitim yönetimi alanını ise kendi sınırlarını şekillendiren ve kendi araştırma alanını belirleyen entelektüel bir alan olarak tanımlamıştır. Eğitim yönetimi alanında akademisyenler, uygulayıcılar ve girişimciler olmak üzere üç temel pozisyon bulunmaktadır. Akademisyenler üniversitelerde öğretim görevini üstelenen ve bilimsel yayın üreten kimselerdir. Uygulayıcılar okullarda görev yapan öğretmen ve yöneticilerdir. Girişimciler ise yönetim konusunda eğitimler düzenleyen ve bunların pazarlamasını yapan ve aynı zamanda raporlama ve araştırma yapan kişilerdir (Fitz, 1999). Bush (2006) eğitim yönetimini, eğitim örgütlerinin işleyişi ve eğitimin amaçları ile ilgilenen bir çalışma ve uygulama alanı olarak tanımlamıştır. Özdemir (2011) ise eğitim yönetiminin uygulama ağırlıklı bilimsel bir inceleme alanı olduğunu ifade etmiştir. Eğitim yönetiminin bir meslek dalı ya da bilim olup olmadığı sorusunu yanıtlayabilmek için öncelikle bilimin ne olduğunu incelemek gerekmektedir. Bilimin, nesnel bilgi, bilimsel metotlar ile üretilen bilgi, bir alandaki sistematik bilgi birikimi, deney ve gözlem vasıtasıyla gelişen dinamik bir süreç (Çelik, 1997) şeklinde tanımlamaları bulunmaktadır. Bilimin tanımının yanı sıra bilim olmanın ölçütleri de eğitim yönetiminin bilim olup olmadığı konusunda ipuçları sunmaktadır (Balcı, 2008). 2009 yılında Gulbenkian komisyonu tarafından hazırlanan "Sosyal Bilimleri Açın" adlı raporda bir bilimin kurumsal hale gelmesi için gereken ölçütler şu şekilde belirtilmiştir: 
1- Üniversitelerde kürsü ya da bölümün olması

2- Bir araştırma alanının olması (araştırmanın kurumsallaşması)

3- Uzmanlık gerektiren bir bilgi birikimine sahip olması, diploma veren ders programlarının olduğu bölüm ya da birimlerinin olması (öğretimin kurumsallaşması)

4- Ürün ya da birikimini sunma olanağı olan bilimsel dergilerin olması

5- Üyelerinin örgütlenmesi

Balcı (2008) bu ölçütlere göre eğitim yönetiminin bir bilim dalı olduğunun şüphe götürmeyen bir gerçek olduğunu ifade etmiştir. Benzer bir biçimde Özdemir (2011) eğitim yönetimi alanının kurumsallaşma sürecinde olan bir bilim olduğunu belirtmiştir. Aynı zamanda yönetim bilimi ve eğitim bilimi arasında sıkışmış ve kendine ait bir kimlik geliştirme ve özerkleşme çabası içinde olan henüz genç bir bilim dalı olduğu ifade edilmektedir (Özdemir, 2018). Glass, Mason ve Eaton (2004) eğitim yönetiminin yeni bir uzmanlık alanı oldunu ifade etmiştir. Hoy (1996) ise eğitim yönetiminde kuramların amacının okul yöneticilerinin uygulamada karşılaştıkları sorunlara çözüm getirme olduğunu ifade ederek alanın uygulama yönünü vurgulamıştır. Benzer bir biçimde Oplatka (2010) eğitim yönetimi alanını uygulamalı bir çalışma alanı olarak ele almıştır.

\section{Eğitim Yönetiminin Tarihsel Gelişimi}

Eğitim yönetimi alanının bilimleşmesi süreci farkıı bakış açılarıyla beslenen uzun bir tarihe sahiptir. Alanın ortaya çıkışından günümüze kadar yaşanan süreçte durgunluk, değişim ve gelişim dönemleri yaşanmıştır (Burgess ve Newton, 2015). Eğitim yönetiminin bir bilim haline gelmesi sürecinin temelleri $A B D^{\prime}$ de atılmıştır. Eğitim yönetiminin düşünsel temelleri Batı kültürü ve toplumundan etkilenmiştir. 1900'lü yıllarında başlarına kadar eğitim yönetimine ilişkin görüşler yalnızca filozofların düşünceleriyle sınırlı kalmış ve eğitim yönetimi bir bilim olma hüviyetine kavuşamamıştır. Eğitim olgusu genellikle felsefe alanında tartışımıştır. Alanın bilimsel uygulamaları eski yöneticilerin anlattıkları hikâyelere ve kişisel deneyimlerine göre sundukları tavsiyelerine göre şekillenmiştir (Heck ve Hallinger, 2005). Ancak modern bilimin doğuşu ile eğitimin bilimsel yaklaşımlar ile incelenmesi gerektiği görüşü hâkim olmuş ve eğitim, bilimin bir konusu haline gelmiştir. Eğitimin felsefeden sıyrılarak bilimin bir konusu haline gelmesinde öğrenme üzerinde yapılan araştırmalar rol oynamıştır. Özellikle Cattell ve Thorndike'ın 1900'lü yılların başında yaptıkları çalışmalar eğitimin bilim olma sürecine önemli katkı sağlamıştır. Eğitimin bu bilimleşme süreci, eğitim yönetiminin de bilimsel ilkelere göre ele alınmasını sağlamıştır. Ayrıca eğitimin kamusal bir hizmet haline gelmesi ile birlikte eğitimde verimlilik arayışları da eğitim yönetiminin bilimleşme sürecine katkıda bulunmuştur. Yönetim konusunun bilimsel olarak incelenmeye başlanması da eğitim yönetiminin bilimsel temellerinin atılmasında diğer bir etken olmuştur. 1727 yılında Kameral Bilim Kürsüleri'nin açılmasıyla yönetimin iktisadi kalkınmanın bir faktörü olarak ele alınması, T.W. Wilson'un yönetim bilimi üzerine yaptığı çalışmalar, Gulick ve Urwick'in yönetim süreçlerine ilişkin görüşleri, Taylor'un yönetimi bilimsel ilkelere dayalı olarak ele alması, Fayol'un ortaya koyduğu yönetim süreçleri de eğitim yönetimi alanının bilimleşme sürecine katkı sağlamıştır (Özdemir, 2018).

Alanyazında eğitim yönetimi alanının tarihsel sürecinin farklı bilim insanları tarafından çeşitli dönemlere ayrılarak

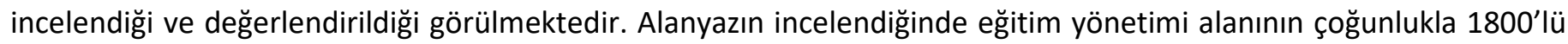
yıllardan itibaren oluşmaya başladığına dair bir görüş birliği olduğu söylenebilir. Murphy (1998) eğitim yönetimi alanının kök salmaya başladığı ilk dönemi ideolojik dönem (1820-1899) olarak adlandırmıştır. Bu dönemde eğitim yönetimi alanı yeni oluşmaya başlamış okul yöneticiliği ise profesyonel bilgi ve beceri gerektirmeyen, deneme yanılma yöntemi ile öğrenilen bir uğraşı olarak ön plana çıkmıştır. Özdemir (2017) birinci dalga olarak adlandırdığı bu ilk dönemde alanın bilgi temelinin oluşmaya başladığını ifade etmiştir. Beycioğlu ve Dönmez (2006) 1850-1920 yılları arasındaki ilk dönemi pozitivizm öncesi dönem olarak adlandırmıştır ve bu dönemde okul yöneticiliğinin değer odaklı bir uğraş olarak ön plana çıktı̆̆ını ifade etmiştir. Papa (2009) ise 1881-1930 yılları arasında geçen süreci okul yönetimi bilimi dönemi olarak adlandırmıştır. Oplatka (2008) 19. yüzyılın son çeyreğini eğitim yönetimin başlangıç noktası olduğunu öne sürerek bu dönemde verimlilik arayışının birçok Amerikan eğitimciyi yönetici yetiştirme programlarına katılmaya teşvik ettiğini belirtmiştir. Eğitim yönetimi alanının tarihsel gelişiminin ayrıldığı dönemlerin farklı isimlerle adlandırıldığı görülse de dönem içerisindeki gelişmelerin benzer bir biçimde ele alındığı söylenebilir.

Okul yöneticilerine yönelik ilk eğitim önce yönetici daha sonra ise Michigan Üniversitesinde eğitim profesörü olarak görev yapan William Payne tarafından verilmiştir (Papa, 2009). Payne'nin okul yönetimine ilişkin görüşlerini topladığı "Chapters on School Supervision" adlı eserinin yayınlanması eğitim yönetiminin bir bilim olma yolunda temellerinin atıldığı 1800 yılların son çeyreğine denk gelmektedir (Burgess ve Newton, 2015). Payne'nin görüşleri ağırlıklı olarak okul yönetiminde verimlilik temelinde işbölümü, planlama, uzmanlaşma ve sorumluluk kavramlarına odaklanması 
bakımından sonraki dönemlere damgasını vuracak olan Taylor'un ortaya koyduğu bilimsel yönetim ilkeleri ile paralellik arz etmektedir (Özdemir, 2017). Murphy'nin (1998) reçete dönemi (1900-1946) olarak adlandırdığı ikinci dönemde eğitimde verimlilik kavramının gündeme geldiği görülmektedir. Amerikan endüstri devriminin ülkedeki ekonomik, siyasi ve sosyal alanları derinden etkilemesi ile birlikte eğitim de doğal olarak bu gelişmelerden etkilenmiştir. Eğitim sistemi, endüstri alanında yakalanan verimliliğin okullarda yer bulamaması nedeniyle eleştiriye uğramış, eğitimcilerden bu hususta çözüm bulmaları istenmiştir. 1911 yılında bir mühendis olan Frederick W. Taylor'un bilimsel yönetim ilkeleri büyük oranda kabul görmüştür. Taylor'un önermiş olduğu sistemde minimum girdi ile maksimum üretimin sağlanması amaçlanmış, verimliliği engelleyen zayıf yönetim ve yavaş çalışma reddedilmiştir. Taylor'un verimlilik anlayışı eğitim alanını derinden etkilemiştir. 1900 yılından itibaren eğitim alanyazınındaki çalışmalar incelendiğinde, bilimsel yönetim ilkelerinin büyük oranda yansımaları görülmektedir. Eğitim yönetiminin bir kontrol tekniği haline gelmesini sağlayan bu ilkeler hâlâ alanda etkilerini göstermektedir (Watkins, 1983).

1900'lü yılların başında, Taylor'un bilimsel yönetim ilkeleri dönemin önde gelen bilim adamları olan Wisconsin Üniversitesi'nden Edward Elliot, Standford Üniversitesinden Ellwood Cubberly ve Columbia Üniversitesi'nden George Strayer tarafından güçlü bir biçimde savunulmuştur (Eacott, 2015). Bu bilim adamları Amerika Birleşik Devletleri'ndeki okullarda verimliliğin uygulanmasına yönelik çalışmalar yapmışlar ve eğitim yönetimi konusunda dersler vermişlerdir (Papa, 2009; Özdemir, 2018). Chicago Üniversitesinde eğitim yönetimi alanında profesör olan John Franklin Bobbitt de alanda verimlilik üzerine çalışmalar yürüten diğer bir bilim insanı olmuştur. Bobbitt, Taylor'un ortaya koymuş olduğu bilimsel yönetim ilkelerini benimsemiş, öğretim programlarında bu ilkelerin kullanılmasını gerektiğini savunmuş ve verimlilik konusu üzerinde durmuştur (Aktan, 2015). Bobbitt (1913) şehir okullarında yönetim adında yayınlanan kitabında bilimsel yönetim ilkelerinin şehir okullarında nasıl uygulanacağına ilişkin bir yazı kaleme almıştır. Bu çalışmasında dile getirmiş olduğu "Eğitim, çelik rayların üretimine benzeyen bir şekillendirme sürecidir." ifadesiyle yazarın, eğitim ve fabrika jargonunu bir arada kullandığını görmek mümkündür. Dönemin önemli bilim insanlarından bir diğeri de okul yönetimi konusunda çalışmalar yapan Jesse B. Sears'dır. Sears bilimsel yönetim ilkelerini benimseyen bilim insanlarının aksine Fayol tarafından geliştirilen yönetim süreçlerinin eğitim örgütlerindeki uygulamasına ilişkin çalışmalarıyla ön plana çıkmıştır (Akt. Özdemir, 2017). Eğitim yönetimi alanının bu ilk kuşak profesörlerinin odaklanmış oldukları temel nokta alanın bilimsel temellerini oluşturmak olmuştur. Diğer bir amaçları ise kendi yerlerini alacak bilim insanlarını yetiştirmektir. Bu dönemde eğitim yöneticiliğinin formel eğitim gerektiren bir meslek haline gelmesi ve giderek kabul görmesi nedeniyle, yöneticiler üniversite eğitimlerine önem vermişlerdir (Murphy, 1998). Ayrıca bu dönemim temel özelliklerinden biri de eğitim yönetimi alanında yapılan çalışmaların çoğunlukla durum çalışmaları ve okul araştırmaları şeklinde olmasıdır (Hallinger ve Chen, 2015).

1950'li yıllardan itibaren kendinden söz ettirmeye başlayan eğitim yönetiminde teori hareketi rasyonalizm ve ampirizme dayalı bilimsel ilkelerin uygulanması yoluyla akademik çalışmaların yapıımasına olan intiyaçtan doğmuştur (Heck ve Hallinger, 2005). Mantıksal pozitivizmin temel felsefesi eğitim yönetimi alanını da etkilemiştir (Çelik, 1997). Eğitim yönetimi alanının kuramsal bir temele sahip olduğu teori hareketi döneminde pozitivizm hakim paradigma olarak eğitim yönetimi alanını uzun süre etkisi altında tutmuştur (Yılmaz, 2018). Murhpy (1998) tarafından bilimsel dönem olarak adlandırılan üçüncü dönemde sosyal bilimlerin çeşitli alanlarından alınan kuramsal katkılar eğitim yönetimi alanında uygulamanın gölgede kalmasına neden olmuştur. Bu dönemde, genel kuramlara ulaşabilmek için çok sayıda veri toplamanın önemi vurgulanmıştır (Beycioğlu ve Dönmez, 2006). Özdemir (2017) eğitim yönetimi bilim çevresinde alandaki uygulamaların teori ile desteklenmesi görüşünün hâkim olduğu bu dönemi "disipliner kurumsallaşma" olarak ifade etmiştir. Bu dönem eğitim yönetimi alanının bağımsız bir meslek haline gelme sürecinin başladığı dönemdir (Balcı, 2008). Teori hareketi döneminde eğitim yönetimi alanında ve yönetici eğitiminde teknik bir bakış açısının ön plana çıktığı görülmektedir (Brundrett, 2001).

Teori hareketi döneminde eğitim yönetimi alanındaki profesörler arasında işbirliği artmış, kongreler düzenlenmiş, akademik dergiler yayınlanmaya başlamış ve pozitivizm temelli bilimsel çalışmalar üretmeye yönelik bir temayül oluşmuştur (Özdemir, 2018). Bu dönemde eğitim yönetiminin bir bilim olarak gelişmeye başlamasında bazı gelişmeler önemli rol oynamıştır. 1947 yılında yazar Walter Cocking ve eğitim yönetimi profesörlerinden Norton'ın öncülüğünde eğitim lideri yetiştirmeye ilişkin sorunları daha iyi anlayabilmek ve bu süreçte kullanılacak yöntem ve tekniklere yönelik ortak bir yaklaşım belirlemek amacıyla Eğitim Yönetimi Profesörleri Ulusal Konferansı (NCPEA) kurulmuştur. Bu kuruluş sayesinde Amerika Birleşik Devletleri'nde eğitim yönetimi alanında çalışmalar yürüten profesörler bir araya gelme ve çalışmalarının eğitim yönetimi çevresinde duyurma imkânı bulmuşlardır. Ayrıca ilk olarak 1946 yılında Kellogg Vakfı eğitim yönetimi alanındaki projelere özellikle de okul yönetimini geliştirmek amacıyla yapılan çalışmalara maddi destek sağlamıştır. Bu kuruluş eğitim yönetimini desteklemek amacıyla yedi milyon dolarlık bir pay ayırmış ve araştırma merkezleri kurmuştur (Özdemir, 2018; Papa, 2009). Daha sonra Kellogg Vakfı'nın desteklediği sekiz üniversitenin ortak çalışmasıyla yönetici yetiştirme programlarında değişiklik yapmak amacıyla hazırlanan Eğitim Yönetimi İşbirliği Projesi 
hayata geçirilmiştir. Bu program yönetime ve okul liderlerinin eğitimine yönelik çok disiplinli bir bakış açısı getirmiş ve yönetici yetiştirme programlarını önemli ölçüde etkilemiştir. Bu gelişmeleri takiben 1955 yılında okul yönetiminde performans belirlemeye yönelik belirli standartlar geliştirmek amacıyla Okul Yönetimi Geliştirme Komitesi (CASA) kurulmuştur (Murhpy, 1998). 1956 yılında daha sonraki yıllarda eğitim yönetimi alanındaki öğretim programlarını ve araştırmaları önemli ölçüde etkileyecek ve yönetici yetiştirme programlarının gelişimine katkıda bulunacak olan Eğitim Yönetimi Üniversite Konseyi (UCEA) kurulmuştur (Willower, 1983).

Eğitim yönetimi alanının bir bilim olarak kendini ispat etmeye çalıştığı teori hareketi döneminde bazı yayın ve araştırmaların alana önemli katkıları olmuştur. Bu çalışmaların temel felsefesi pozitivizme dayanmaktadır. Pozitivizmin yönetim bilimi üzerindeki etkisini gösteren ve sonraki yıllarda eğitim yönetimi alanını da etkileyen önemli bir eser Herbert A. Simon tarafından 1945 yılında yayınlanan ve temel olarak doğa bilimlerinde uygulanan nesnel yöntemlerin yönetim biliminde de uygulanması gerektiğini savunan Yönetsel Davranış isimli kitap olmuştur (Özdemir, 2018). Yönetim alanındaki çalışmaların bilimsel temeli bu esere dayanmaktadır. Simon'un düşüncesi yönetimin doğasına ilişkin tamamen yeni bir düşünce getirmiştir. Yönetim alanına rasyonellik kavramını entegre eden Simon, değerlerden bağımsız bir karar alma sürecinin önemini vurgulamıştır (Greenfield, 1986). Walter Cocking'in editörlüğünü üstlendiği Okul Yönetimi Dergisi de alanın profesyonelleşme sürecine katkıda bulunmuştur. 1954 yılında gerçekleştirilen Eğitim Yönetimi Profesörleri Ulusal Konferansı'nın ardından eğitim yönetimi alanını derinden etkileyecek bazı çalışmaların üretildiği görülmüştür. İlk olarak 1955 yılında Coladarci ve Getzels'in temel olarak eğitim yönetiminde kuramların nasıl kullanılabileceğini anlatan Eğitim Yönetiminde Teori Kullanımı, 1956 yılında Griffiths'in Okul Yönetiminde Insan Ilişkileri ve daha sonra 1957 yılında Campbell ve Greg'in Eğitimde Yönetsel Davranış isimli kitapları yayınlanmıştır (Papa, 2009). Griffiths (1956) eğitim yönetimi alanında daha nitelikli araştırmaların yapılmasını, bu araştırmaların kuramlara dayandırılmasını ve sosyal bilimcilerin eğitim yönetimi alanındaki profesörlere kuramların kullanımı noktasında rehberlik yapmaları gerektiğini ifade etmiştir. 1957 yılında Chicago Üniversitesinde düzenlenen bir seminerden bir sonraki yıl içerisinde Andrew W. Halpin tarafından yapılan sunumların yayınlandığı bir kitap basılmıştır. 1959 yılında Griffiths'in yönetimde bilimsel yöntem ve yaklaşımların önemini vurgulayan Yönetsel Teori adlı çalışması yayınlanmıştır.

Eğitim yönetiminin bilimleşme sürecindeki önemli gelişmelerden biri de bilimsel dergilerin yayınlanmaya başlamış olmasıdır. Bu dergiler 1963 yılında Avusturalya'da yayın hayatına başlayan Journal of Educational Administration ve 1965 yılında ABD'de yayınlanan Education Administration Quarterly isimli dergilerdir. Bunları takiben, 1972 yılında Ingiltere'de Educational Management Administration and Leadership adlı dergi yayınlanmaya başlamıştır (Beycioğlu ve Dönmez, 2006; Özdemir, 2017). Ayrıca ABD’de Ulusal Ortaokul Müdürleri Derneği (National Association of Secondary School Principals) tarafından ilk sayısı 1917 yılında yayınlanan NASSP Bulletin ve 1943 yılında yayınlanmaya başlayan Educational Leadership adlı dergiler de eğitim yönetimi alanına daha çok uygulamaya dönük yayınlar yapmışlardır. Bu dergiler eğitim yönetimi alanındaki çalışmalara yön vermesi, alandaki çalışmaların geniş bilim çevrelerine yayılması ve yapılacak yeni yayınları teşvik etmesi bakımından önemli görülebilir.

Teori hareketi döneminde uygulama yönü ön planda olan eğitim yönetimi bir dönüşüm yaşayarak kuramsal ve akademik bir boyut kazanmıştır (Balcı, 2008). Ayrıca bu dönemde eğitim yönetimi kuram ve uygulama boyutu doğrudan ilişkili olan ancak kuramın uygulamayı belirlediği bir kavram haline gelmiştir (Sergiovanni, 1991). Bu dönemde alanın uygulama boyutu ikinci plana atılmış, bilim insanları bilimsel araştırmanın önemini vurgulamış ve örgütleri daha iyi anlayabilmek için kuramsal bilgiye bağlı kalmak gerektiğini ifade etmişlerdir (Oplatka, 2009). Teori hareketi döneminde bilim adamları araştırmacıları başta psikoloji ve sosyoloji olmak üzere başka alanların teorik temellerini eğitim yönetimi alanında uygulamaya ve daha çeşitli araştırma deseni ve yöntemler kullanmaya teşvik etmişlerdir (Hallinger ve Chen, 2015). Dönemin en belirgin özelliği sadece nicel yöntemlere dayalı ampirik çalışmalarının öneminin vurgulanmasıdır. Bu da teori hareketi döneminde alanın gelişiminin bilim ve toplumun sahip olduğu pozitivist bakış açısından etkilendiğini ortaya koymaktadır (Oplatka ve Arar, 2018). Teori hareketi döneminde eğitim yönetimi alanının bir bilim haline getirilme çabasının yoğun bir biçimde yaşandığı söylenebilir. Bu dönem alanda önde gelen bilim insanlarının eğitim yönetimine kuramsal bir temel oluşturma arayışında çeşitli çalışmalar yaparak alanın bağımsız bir bilim olmasının temellerinin atıldığı bir dönem olarak görülebilir.

Teori hareketinin eğitim yönetimi alanına kazandırdığı pozitivizm odaklı entelektüel anlayış ve ampirik araştırma geleneği ilerleyen dönemlerde başta Thomas B. Greenfield, R. Bates ve C. Hodgkinson olmak üzere farklı görüşlere sahip bilim insanlarının sert eleştirilerine maruz kalmıştır. Bu bilim insanları nicel analizlere dayalı davranışçı yaklaşımların okulların sosyal yapılarına uymadığını öne sürmüşlerdir. Ayrıca eğitim yöneticilerinin düşünce ve eylemleri üzerinde etkisi olan bağlamsal ve etik konuları ihmal ettiğini vurgulamışlardır (Heck ve Hallinger, 2005). Eğitim yönetiminde ortaya çıkan öznellik ve görelilik kavramlarını vurgulayan yeni yaklaşımın temellerini Thomas S. 
Kuhn tarafından 1962 yayınlanan "Bilimsel Devrimlerin Yapısı" adlı eserinde ortaya koyduğu paradigma kavramı oluşturmuştur (Özdemir, 2018). Paradigma kavramı bir dünya görüşü ve bakış açısı olarak tanımlanmıştır. Geleneksel bilim anlayışına göre bilim birikimli bir şekilde ilerlemekte ve birbirine bağlı parçalardan oluşmaktadır. Ancak paradigma yaklaşımına göre bilimde değişim devrim şeklinde meydana gelmektedir ve yeni paradigma bir öncekinin yerini almaktadır (Şimşek, 1997).

Paradigma kavramının eğitim yönetimine yansımasının öncüsü olan Greenfield (1986), örgütlerin nesnel yapılar olmadığını, insanlar tarafından oluşturulan sosyal gerçeklikler olduğunu, üretim ve teknik kontrol gibi kavramların örgütleri anlama ve yönetmede yetersiz kalacağını ve yöneticilerin değerlerden bağımsız bir yaklaşım sergileyemeyeceğini ifade ederek, teori hareketi döneminin hâkim paradigması olan pozitivizmin temellerini sarsmıştır. Yazara göre bilimsel yönetim güç ilişkilerini göz ardı etmekte, eğitimdeki gerçek problemlere odaklanmamakta, örgütleri toplumun gerçek aktörleri olan insanlardan oluşan sosyal yapılar olarak görmemekte ve insanı değersizleştirmektedir. Ayrıca araştırmalarda nitel araştırma yönteminin kullanılmasının daha uygun olacağını ifade ederek eğitim yönetimi araştırmalarında yöntemsel bir yenilik de başlatmıştır. Greenfield'in öznellik kavramı ve insanların gerçeklikleri kendilerine has bir biçimde yorumlamaları gibi hususları vurgulaması bakımından Kant'ın idealizm felsefesinden etkilendiği ifade edilmektedir (Özdemir, 2017).

Eğitim yönetimi alanında pozitivist yaklaşıma karşı çıkan diğer bir yaklaşım da eleştirel teoridir. Eleştirel teoriye göre eğitim yönetimi alanındaki teorilerin temel amacı insan ve toplumu özgür hale getirmektedir. Her okulda uygulanabilecek yönetim yaklaşımları farklıdır. Çünkü her okulun kendine özgü bir yapısı vardır ve okuldaki roller yöneticilerin sosyal algılarına göre değişmektedir. Bu bağlamda okul ortamı çalışanların eleştiri yapabileceği biçimde hazırlanmalıdır (Turan, 2004). Bu kuramın savunucularından olan Bates (1982) yönetimde rasyonelliğin bir krize yol açtığını savunarak bilimsel yönetim yaklaşımının yönetimde bir değerler sistemi oluşturmanın önüne geçebileceğini ve insanları birleştirici unsurlardan olan kültürün oluşturulmasını engelleyebileceğini ifade etmiştir. Benzer bir biçimde C. Hodgkinson da yönetimin bilimsellikten ziyade felsefi olarak ele alınması gerektiğini savunarak yönetimde değer temasının önemini vurgulamış ve bilimsel yönetim anlayışını eleştirmiştir (Özdemir, 2018). Pozitivist paradigmaya karşı eleştirilerden biri de eğitim yönetimi alanında kuram ve uygulamanın doğasına ilişkin yeni bir bakış açısı ortaya koyan Evers ve Lakomski tarafından yapılmışır. Yazarlar ampirik yaklaşımların bilimin değerine katkıda bulunmadığını ifade etmişler, bilimin en iyi post-pozitivist bir bakış açısı ile anlaşılabileceğini savunmuşlardır. Bilime yönelik kendi felsefelerini ise uygulanabilir bir nesnellik kavramı sağlayan tutarlılık (coherentism) olarak ortaya koymuşlardır (Evers ve Lakomski, 2001).

$1980^{\prime}$ li yıllardan itibaren eğitim yönetimi alanında hem üniversitelerde hem de okullarda kavramsal bir çeşitlilik oluşmaya başlamıştır. Rol model olma ve mentörlük kavramları ortaya çıkmıştır. Cinsiyet ve ırk ayrımcılı̆̆ı konusundaki araştırmaların sayısında büyük bir artış yaşanmıştır. Eğitimde sosyal ve kültürel etkiler, okul gelişimi, politika, liderlik ve etik kavramları tartışımaya başlamıştır. Bu kavramsal çeşitlilik eğitim yönetimi alanında yeni araştırma konularının ortaya çıkmasına neden olmuştur (Papa, 2009). Bu dönemde eleştirel teori, post-modernizm ve feminizm yaklaşımları eğitim alanında yapılan çalışmaları yoğun bir biçimde etkilemiştir. Araştırma konuları büyük oranda sosyal kaygıların bir yansıması olarak ortaya çıkmıştır (Heck ve Hallinger, 2005). Bu yıllarda yoksul şehir okulları temelinde okullarda etkili öğretimin gerçekleştirilmesine yönelik faktörlerin araştırılmasına ağırlık verilmiştir. Okul etkililiğine yönelik araştırmalar kısa süre içinde eğitim politikalarını önemli ölçüde etkilemiştir (Hallinger ve Murphy, 1986). Bu dönemde başlayan etkili okul hareketiyle birlikte okul müdürünün okul etkililiği üzerinde önemli rol oynadığı ve okul başarısını etkileyen bir öğretim lideri olduğu görüşü ön plana çıkmıştır (Hallinger, 2005). Murphy (1998) diyalektik dönem adını verdiği bu süreçte bilimsel dönemden bilim sonrası döneme geçişin söz konusu olduğunu ifade etmiştir. Diyalektik dönemde okul yöneticilerine ve yönetici yetiştirme programlarına ağır eleştiriler yapılmış ve okul yöneticilerinin nasıl yetiştirilmesi gerektiğine yönelik alternatifler sunulmuştur. Okul yöneticilerinin eğitimdeki sorunların temel nedeni olduğu, okullardaki sorunları çözmede yetersiz kaldıkları ve işlevsel olmayan ve yüksek maliyetli bürokrasi sistemini savunan bir yönetici profili çizdikleri eleştirilerin temel gerekçeleri olmuştur (Murphy, 1991). Greenfield'in alana yeni bir bakış açısı getirmesiyle başlayan bu süreçte yaşanan değişim bazı sorunları da beraberinde getirmiştir. Farkı kavramsal ve yöntemsel yaklaşımlar geliştiren bilim adamları birbirlerini görmezden gelmişlerdir. Görüşlerini farklı bilimsel temellere dayandırmışlardır. Bu durum alandaki bilgi temelinin artmasına katkıda bulunmamıştır çünkü araştırmalardan elde edilen sonuçlar hem uygulayıcıların hem de politika yapıcıların sağlıklı bir biçimde kullanabileceği şekilde somut bilgiye dönüştürülmemişlerdir (Heck ve Hallinger, 2005). Bu ifadeleri destekler nitelikte, bu dönemi Özdemir (2017) "epistemik buhran", Griffiths (1979) ise "entelektüel karmaşa" olarak tanımlamıştır. 


\section{Eğitim Yönetiminin Bilimleşme Sürecinin Türkiye'deki Yansımaları}

Türkiye Cumhuriyeti'nin kuruluşunun ilk dönemlerinde eğitim yöneticiliğinin başlı başına bir meslek olarak görülmemesi nedeniyle eğitim yönetimi alanının epistemolojik temelleri atılamamıştır. Bu dönemde Türkiye'deki eğitim sisteminin gelişiminde yabancı bilim insanlarına danışılması eğitim yönetiminin yeterince gelişmediğinin göstergesi olarak değerlendirilmektedir (Özdemir, 2017). 3 Mart 1924 tarihinde Türk Milli Eğitiminde yeni bir yapılanma girişimi olarak Tevhid-i Tedrisat Kanunu kabul edilerek eğitimde birliğin sağlanması amacıyla farklı işlevlere sahip olan okullar birleştirilmiştir. Aynı zamanda Bakanlık örgüt yapısı da bu amaç doğrultusunda yeniden yapılandırılmıştır. 1926 yılında yayınlanan 789 sayılı Maarif Teşiklatına Dair Kanunda yer alan "Meslekte aslolan öğretmenliktir" maddesi, okul yöneticiliğinin öğretmenler tarafından yürütülebilecek olan bir alt görev olarak ele alınmasına neden olmuştur (Cemaloğlu, 2005). Bu durum okul yöneticiliğinin ayrı bir meslek olarak görülmediğini ortaya koymaktadır. Eğitimdeki yeniden yapılanma sürecinde okullardaki eğitici ve yöneticilerin yetiştirilmesi amacıyla 1928 yılında Pegadoji Bölümü Gazi Eğitim Enstitüsüne bağlı olarak açılmıştır (Balcı, 2008).

1950'li yıllardan itibaren ABD'de başlayan eğitim yönetiminde teori hareketinin yankıları Türkiye'de de hissedilmiştir. Eğitim ve eğitim yönetimi ilgi odağı haline gelmiştir (Özdemir, 2017). Bu bağlamda, kamusal alanda hizmet veren yöneticilerin bilimsel bir anlayışla eğitimlerini sağlamak amacıyla 1953 yılında Türkiye ve Orta Doğu Amme İdaresi Enstitüsü (TODAIE) hizmete açılmıştır. Kamu yönetimi alanında genel bir yöneticilik bilinci kazandırmayı kısmen başarabilen programın eğitim yöneticileri ve öğretmenlere yönetsel bilgi ve becerileri yeterince kazandırıp kazandıramadığı tartışma konusu olmuştur. 1962 yılında yayınlanan Bakanlar Kurulu kararı ile ilan edilen Merkezi Hükümet Teşkilatı Araştırma Projesi (MEHTAP) raporu da okul yöneticilerinin yetiştirilmesine ilişkin hususlar ihtiva etmesi açısından eğitim yönetimi alanında bir gelişme olarak gösterilebilir (Balcı, 2008). 1950'lerden itibaren ortaya çıkan teori hareketi ile birlikte eğitim yönetimi alanı Türkiye'de de bilimsel olarak ele alınmaya başlanmış ve alanın öncüleri bilgi ve becerilerini geliştirmek amacıyla ABD’ye gönderilmiştir. Bu bilim insanlarının yayınladıkları eserler kuramın önemini vurgulayan eğitim yönetiminde teori hareketinin Türkiye' de yayılmasına neden olmuştur. Eğitim yönetimi alanının Türkiye'de kurumsal temellerinin atılmasının öncüsü olan Ziya Bursalıoğlu’nun 1960'lı yıllarda ortaya koyduğu çalışmalar alanda teori hareketinin yansıması olarak ortaya çıkmıştır. Bu çalışmalar okul yönetimi uygulamalarında teorinin önemine işaret etmiştir. Ayrıca Haydar Taymaz, İbrahim Ethem Başaran, Mustafa Aydın, Mahmut Adem, Yahya Kemal Kaya, Kemal Güçlüol ve Galip Karagözoğlu gibi bilim insanları da Türkiye'de eğitim yönetimi alanının kurumsallaşması ve yerleşmesinde önemli rol oynamışlardır (Özdemir, 2018; Yılmaz, 2018).

1962 yılında toplanan Yedinci Milli Eğitim Şurası'nın eğitim yöneticilerinin bilimsel bir yaklaşımla yetiştirilmeleri yönündeki tavsiyeleri doğrultusunda Ankara Üniversitesi Eğitim Fakültesi 1964 yılında kurulmuştur. Eğitim fakültesine bağlı olarak Eğitim Yönetimi, Teftişi, Planlaması ve Ekonomisi Bölümü açılmış ve lisans düzeyinde eğitim vermeye başlamıştır. İzleyen dönemlerde Hacettepe, Gazi, İstanbul, Dokuz Eylül ve Abant İzzet Baysal Üniversitelerinde de aynı bölümler açılarak Türkiye'de yönetici ve müfettişlerin bilimsel ilkelere dayalı olarak yetiştirilmesinde önemli rol oynamışlardır. Ancak 1997 yılında Yükseköğretim Kurulu'nun kararıyla lisans eğitimi veren bu bölümleri kapatılmıştır. Günümüzde bu bölümlerde lisansüstü düzeyde eğitim verilmektedir (Cemaloğlu, 2005). 2018-2019 Eğitim-öğretim yılı itibariyle Türkiye'de Eğitim Yönetimi alanında eğitim veren 79 Eğitim Yönetimi Anabilim Dalında 400'ü aşkın öğretim elemanı bulunmaktadır. Alanda yüksek lisans düzeyinde yaklaşık 7200, doktora düzeyinde ise yaklaşık 700 öğrenci eğitim görmektedir (YÖK, 2019). Eğitim Yöneticileri ve Eğitim Deneticileri Derneği'nin (EYEDDER) ve Eğitim Yöneticileri ve Uzmanlar Derneği'nin (EYUDER) kurulması ve eğitim yönetimi alanında düzenlenen Ulusal Eğitim Yönetimi Kongresi (EYK) ve Eğitim Yönetimi Forumu (EYFOR) gibi bilimsel toplantılar Türkiye' de alana katkı sağlayan gelişmelerdir. Ayrıca 1995 yılında Kuram ve Uygulamada Eğitim Yönetimi ve 2016 yılında EYEDDER tarafından Research in Educational Administration and Leadership (REAL) dergilerinin yayınlanması eğitim yönetimi alanının zengileşmesine katkıda bulunan diğer gelişmeler olarak gösterilebilir.

Türkiye' de eğitim yönetimi alanının araştırmaların niteliği ve alanın bilgi temeli açısından son zamanlarda kısmen de olsa sorgulandığı görülmektedir (Yılmaz, 2018). Balcı ve Apaydın (2009) eğitim yönetimi alanındaki araştırmaların çoğunlukla uygulamaya dönük nicel desenli çalışmalar olduğunu ifade etmişlerdir. Benzer bir biçimde Yılmaz (2018) Türkiye'de eğitim yönetimi alanında büyük oranda nicel çalışma geleneğinin hâkim olduğunu ve eğitim yönetimi alanının pozitivist karakterinin genellikle alana zarar veren olumsuz bir durum olarak algılandığını ifade etmiştir. Ancak, yorumsamacı ve öznel yaklaşımların eğitim alanında önemli değişimlere neden olmasıyla birlikte Türkiye' de 1990'lardan itibaren hâkim paradigma olan pozitivist anlayışın izlerini taşıyan nicel temelli araştırmalar eleştiriye uğramış, nitel araştırma teknikleri de kullanılmaya başlanmıştır (Özdemir, 2017). Bu durumu destekler nitelikte Yılmaz (2018) Türkiye'de son yıllarda nitel çalışmalarının sayısının arttığını ifade etmiştir. Ayrıca özerkleşme, liderlik ve öğrenci odaklılık gibi kavramlar da son dönemlerde alanda yer bulmuştur. Eğitim yönetimi alanının ortaya çıktığı 
ülkelerde diğer sosyal bilim alanlarına göre daha yavaş bir biçimde gelişme gösterdiği ifade edilmektedir. Ancak Türkiye'de eğitim yönetimi alanı hızlı bir ivme ile geliştiği bunun da alandaki uzmanların gelişmiş ülkelerde edindikleri bilgi ve deneyimleri ülkemizde aktarması ile mümkün olduğu belirtilmiştir (Balcı, 2008).

\section{Tartışma ve Sonuç}

Bu çalışmada eğitim yönetimi alanının tarihsel seyir içinde yaşadığı bilimleşme süreci incelenmiştir. Bu bağlamda öncelikle eğitim yönetimi alanının bir bilim olup olmadığına ilişkin tartışmalara ilişkin farklı görüşlere yer verilmiş ve bu tartışmaların gerekçeleri sunulmuştur. Daha sonra eğitim yönetiminin tanımı yapılmış ve bir bilim olmak için gereken kriterlere sahip olup olmadığı irdelenmiştir. Son olarak eğitim yönetimi alanının ABD'de temelleri atılan bilimleşme süreci 18. yüzyılın sonlarından başlanarak inceleme konusu edilmiştir. Eğitim yönetiminin tarihsel süreç içinde bilim olup olmadığına ilişkin yoğun tartışmalar yaşanmıştır. Eğitim yönetiminin son yıllarda yakaladığı ivmeye rağmen kendine özgü bir kuramsal bilgi temeli ve bilgi birikimi olmadığı, araştırma konularını farklı bilim dallarından alması, kuram ve uygulama tartışmaları arasında sıkışması, pozitivizm odaklı olması, eğitimsel yönünün zayıf olması ve epistemik çevresinde alana ilişkin bir görüş birliği bulunmaması gibi gerekçelere dayalı yapılan eleştiriler alanı önemli ölçüde etkilemiştir. Alanyazın incelendiğinde eğitim yönetiminin işletme yönetimi, kamu yönetimi, sosyoloji ve psikoloji gibi bilimlerin etkisi altında gelişmesinin alanın kendine özgü bir bilim dalı olup olmadığına ilişkin tartışmaların ortak noktası olduğu görülmektedir. Ancak özellikle 1950'li yıllardan ABD'de ortaya çıkan eğitim yönetiminde teori hareketi ile eğitim yönetimi alanı kendine özgü sınırlarını çizmeye başlamış ve bağımsız bir bilim olarak ortaya çıkma süreci başlamıştır. Bu bağlamda eğitim yönetimi üniversitelerde kürsüsü bulunan, diploma dereceleri sunan, kendine özgü araştırma konuları olan, bilimsel dergi ve yayınları bulunması açısından bağımsız bir bilim olarak görülmeye başlanmıştır.

Türkiye'de cumhuriyetin ilk yıllarında eğitim yöneticiliğinin bir uzmanlık alanı olarak görülmemesinin alanın kendine özgü bir bilgi temeli oluşturamamasında etkili olduğu söylenebilir. Bu durumun nedeni olarak okul yöneticiliğinin öğretmenlik mesleği kapsamında yürütülen bir alt görev olarak görülmesi gösterilebilir. İlerleyen yıllarda ABD'de ortaya çıkan kuram hareketinin yansımaları Türkiye'de de görülmeye başlamıştır. Bu dönemde yapılan çalışmalarla birlikte eğitim yönetimi bilimsel olarak ele alınmaya başlamıştır. Üniversitelerede açılan bölümler, bilimsel dergilerin yayınlanması, bilimsel kongrelerin düzenlenmesi ve derneklerin kurulması gibi gelişmeler eğitim yönetimi alanının zenginleşmesine neden olmuştur. Ancak günümüzde Türkiye'de eğitim yönetimi alanında halen tartışmaların devam ettiği görülmektedir. Bu tartışmaları kuram ve uygulama alanlarındaki sorunların yansıması olarak karşımıza çıkmaktadır. Eğitim yöneticiliğinin profesyonel bir yapıya kavuşturulamaması eğitim yönetiminin hakettiği değeri görmesi önünde önemli bir engel teşkil etmektedir. Bu bağlamda, Türkiye'de nitelikli okul yöneticileri yetiştirmeye yönelik politikaların üretilmesi ve işe koşulması gerektiği söylenebilir. Türkiye'de eğitim yönetimindeki alanında yaşanan tartışmaların bir diğeri de kuramsal bilgi temeline yöneliktir. Yapılan araştırmalar alandaki kuramların başka bilimlerden ya da ülkelerden alındığını ortaya koymaktadır. Ancak eğitim yönetiminin kültürel bağlamı dikkate alındığında başka ülkelerde geliştirilen kuramların Türkiye'nin kendi kültürel koşullarına uyarlanmadan kullanılması olumsuz bir durumdur (Yılmaz, 2018). Ayrıca bu durum Türkiye'de eğitim yönetiminde yaşanan sorunlarının çözülmesinde etkili olmayabilir. Çünkü ülkelerin eğitim sorunları kendine has çözümler gerektirebilir. Bu bağlamda Türkiye'de eğitim yönetimi alanında yapılan araştırmaların ülkenin eğitim sorunlarının çözümünde bir yol haritası sunabilecek olan kuramsal bilginin üretilmesine katkı sağlamaları gerektiği söylenebilir.

Eğitim yönetimi alanı gelişme sürecinde çeşitli bilim dallarından etkilense de bir bilim olarak inceleme konusu edilmeye başlandığı andan itibaren bağımsız bir alan olmak için çaba göstermektedir. Eğitim yönetimi, doğuşundan başlayarak günümüze kadar gelen süreç içinde çeşitli görüş ve yaklaşımların etki alanında olmuştur. Bu durum eğitim yönetiminin kendine özgü bir bilimsel disiplin haline gelmesinde yavaşlatıcı bir rol oynamıştır. Ayrıca eğitim yönetiminde hâkim araştırma geleneğinde kuramsal çalışmaların yeterince yer bulamaması da eğitim yönetiminin bilimsel bir yapı kazanmasını olumsuz yönde etkilediği söylenebilir. Bu bağlamda eğitim yönetimi alanının bilgi birikimine katkıda bulunacak kuramsal çalışmalara ihtiyaç duyulduğu düşünülmektedir. Eğitim yönetimi alanında yapılan çalışmaların eğitimin vazgeçilmez parçası olan okullara ve genel anlamda bir ülkenin eğitim sistemine katkı sağlamasının beklenmesi doğal bir durumdur. Ancak yapılan çalışmaların aynı zamanda eğitim yönetimi alanını daha ileri taşıyacak ve kendine özgü sınırları olan bir bilim haline gelmesine de katkıda bulunması gerekmektedir. Ayrıca eğitim yönetimi alanındaki akademisyenlerin alanın mevcut durumuna ve geleceğine ilişkin bir kaygı taşımaları ve bu doğrultuda bir görüş birliği oluşturmak adına çaba göstermeleri gerekmektedir. Eğitim yönetimi alanının eğitim sistemine ve topluma katkı sağlama düzeyi bir bilim olarak gördüğü değere bağıı olacaktır. 


\section{Kaynakça}

Aktan, S. (2015). John Franklin Bobbitt'te program düşüncesinin gelişimi: Tarihsel bir inceleme. Electronic Turkish Studies, 10(15), 35-50.

Amadi-Eric, C. (2008). Introduction to Educational Administration: A module. Port Harcourt: Harey Publications.

Aldrich, R. (2014). In search of 'time-tested truths': historical perspectives on educational administration. Journal of Educational Administration and History, 46(2), 220-233.

Anderson, G. L., \& Grinberg, J. (1998). Educational administration as a disciplinary practice: Appropriating Foucault's view of power, discourse, and method. Educational Administration Quarterly, 34(3), 329-353.

Aslanargun, E. (2007). Modern eğitim yönetimi anlayışına yönelik eleştiriler ve postmodern eğitim yönetimi. Kuram ve Uygulamada Ĕgitim Yönetimi, 50(50), 195-212.

Balcı, A. (2008). Türkiye'de eğitim yönetiminin bilimleşme düzeyi. Kuram ve Uygulamada Egitim Yönetimi Dergisi, 14(2), 181-209.

Balcı, A. (2011). Eğitim yönetiminin değişen bağlamı ve eğitim yönetimi programlarına etkisi. Eğitim ve Bilim, 36(162).

Balcı, A., \& Apaydın, Ç. (2009). Türkiye'de eğitim yönetimi araştırmalarının durumu: Kuram ve uygulamada eğitim yönetimi dergisi örneği. Kuram ve Uygulamada Egitim Yönetimi Dergisi, 15(3), 325-344.

Bates, R. (1982). Toward a critical practice of educational administration. Paper presented the Annual Meeting of the American Educational Research Association, New York.

Bates, R. (1983). Educational administration and the management of knowledge. Publication Sales, Deakin University Press, Victoria 3217, Australia.

Bates, R. (2013). Educational administration and the management of knowledge: 1980 revisited. Journal of Educational Administration and History, 45(2), 189-200.

Beycioğlu, K., \& Dönmez, B. (2006). Eğitim yönetiminde kuramsal bilginin üretimine ve uygulanmasına ilişkin bir değerlendirme. Kuram ve Uygulamada Eğitim Yönetimi, 47(47), 317-342.

Burgess, D., \& Newton, P. (Eds.). (2015). Educational administration and leadership: Theoretical foundationsNew York: Routledge.

Bush, T. (1999). Crisis or crossroads? The discipline of educational management in the late 1990s. Educational management \& Administration, 27(3), 239-252.

Bush, T. (2006). Theories of Educational Management. International Journal of Educational Leadership Preparation, 1(2), 1-25.

Bush, T. (2007). Educational leadership and management: Theory, policy and practice. South African Journal of Education, 27(3), 391-406.

Brundrett, M. (2001). The development of school leadership preparation programmes in England and the USA: A comparative analysis. Educational Management \& Administration, 29(2), 229-245.

Can, N. (Ed.). (2018). Kuram ve uygulamada eğitim yönetimi. Ankara: Pegem.

Cemaloğlu, N. (2005). Türkiye de okul yöneticisi yetiştirme ve istihdamı varolan durum, gelecekteki olası gelişmeler ve sorunlar. Gazi Üniversitesi Gazi Eğitim Fakültesi Dergisi, 25(2), 249-274.

Çelik, V. (1997). Eğitim yönetiminde kuramsal gelişmeler. Kuram ve Uygulamada Egitim Yönetimi Dergisi, 3(1), 31-44.

Eacott, S., \& Evers, C. (2015). New Frontiers in Educational Leadership. Management and Administration Theory, 47(4), 307-311.

Eacott, S. (2015). Educational leadership relationally: A theory and methodology for educational leadership, management and administration. Springer.

Eacott, S. (2017). A social epistemology for educational administration and leadership. Journal of Educational Administration and History, 49(3), 196-214. 
English, F. W. (2001). What paradigm shift? An interrogation of Kuhn's idea of normalcy in the research practice of educational administration. International Journal of Leadership in Education, 4(1), 29-38.

English, F. W. (2002). The point of scientificity, the fall of the epistemological dominos, and the end of the field of educational administration. Studies in Philosophy and Education, 21(2), 109-136.

Erickson, D. A. (1979). Research on educational administration: The state-of-the-art. Educational Researcher, 8(3), 914.

Evers, C. W., \& Lakomski, G. (2001). Theory in educational administration: naturalistic directions. Journal of Educational Administration, 39(6), 499-520.

Fitz, J. (1999). Reflections on the field of educational management studies. Educational Management \& Administration, 27(3), 313-321.

Fitzgerald, T., \& Gunter, H. M. (2008). The state of the field of educational administration. Journal of Educational Administration and History, 40(2), 81-83.

Glass, T. E., Mason, R., \& Eaton, W. (2004). The history of educational administration viewed through its textbooks. Oxford: R\&L Education.

Gorard, S. (2005). Current contexts for research in educational leadership and management. Educational Management Administration \& Leadership, 33(2), 155-164.

Greenfield, T. B. (1986). The decline and fall of science in educational administration. Interchange, 17(2), 57-80.

Griffiths, D. E. (1956). Human relations in school administration. Appleton-Century-Crofts.

Griffiths, D. E. (1979). Intellectual turmoil in educational administration. Educational Administration Quarterly, 15(3), 43-65.

Hallinger, P. (2005). Instructional leadership and the school principal: A passing fancy that refuses to fade away. Leadership and policy in schools, 4(3), 221-239.

Hallinger, P., \& Chen, J. (2015). Review of research on educational leadership and management in Asia: A comparative analysis of research topics and methods, 1995-2012. Educational Management Administration \& Leadership, 43(1), 5-27.

Hallinger, P., \& Kovačević, J. (2019). A bibliometric review of research on educational administration: science mapping the literature, 1960 to 2018. Review of Educational Research, 89(3), 335-369.

Hallinger, P., \& Murphy, J. F. (1986). The social context of effective schools. American journal of education, 94(3), 328355.

Heck, R. H., \& Hallinger, P. (2005). The study of educational leadership and management: Where does the field stand today?. Educational Management Administration \& Leadership, 33(2), 229-244.

Hoy, W. K. (1996). Science and theory in the practice of educational administration: A pragmatic perspective. Educational Administration Quarterly, 32(3), 366-378.

Kochan, F. K. (2002). Hope and possibility: Advancing an argument for a Habermasian perspective in educational administration. Studies in Philosophy and Education, 21(2), 137-155.

Maxcy, S. J. (2001). Educational leadership and management of knowing: The aesthetics of coherentism. Journal of Educational Administration, 39(6), 573-588.

Murphy, J. (1991). Restructuring schools: Capturing and assessing the phenomena. Teachers College Press.

Murphy, J. (1998). Preparation for the school principalship: The United States' story. School Leadership \& Management, 18(3), 359-372.

Oplatka, I. (2008). The field of educational management: Some intellectual insights from the 2007 BELMAS national conference. Management in Education, 22(3), 4-10.

Oplatka, I. (2009). The field of educational administration: A historical overview of scholarly attempts to recognize epistemological identities, meanings and boundaries from the 1960s onwards. Journal of Educational Administration, 47(1), 8-35. 
Oplatka, I. (2010). The legacy of educational administration: A historical analysis of an academic field. Frankfurt: Peter Lang.

Oplatka, I., \& Arar, K. H. (2016). Leadership for social justice and the characteristics of traditional societies: ponderings on the application of western-grounded models. International journal of leadership in education, 19(3), $352-369$.

Örücü, D., \& Şimşek, H. (2011). Akademisyenlerin gözünden Türkiye'de eğitim yönetiminin akademik durumu: Nitel bir analiz. Kuram ve Uygulamada Egitim Yönetimi Dergisi, 17(2), 167-197.

Özdemir, M. (2011). Kamu yönetimi ve işletme yönetimi arakesitinde bir bilim: Eğitim Yönetimi. Amme idaresi Dergisi, $44(2), 29-42$.

Özdemir, S. (2013). Türk eğitim sistemi ve okul yönetimi. Pegem: Ankara.

Özdemir, M. (2017). Eğitim yönetiminde epistemik bunalımın arkeolojisi. Kuram ve Uygulamada Egitim Yönetimi Dergisi, 23(2), 281-304.

Özdemir, M. (2018). Eğitim yönetimi: Alanın temelleri ve çağdaş yönelimler. Ankara: Anı.

Paige, R. M., \& Mestenhauser, J. A. (1999). Internationalizing educational administration. Educational Administration Quarterly, 35(4), 500-517.

Papa, R. (2009). The discipline of education administration: Crediting the past. 19.03 .2018 tarihinde https://www.researchgate.net/profile/Rosemary_Papa/publication/284826629_Transitions_in_Teaching_and_ eLearning/links/578400d308aee45b8442ef21.pdf adresinden erişim sağlanmıştır.

Park, J. (2015). Thematic approach to theoretical speculations in the field of educational administration. Educational Philosophy and Theory, 47(4), 359-371.

Samier, E. (2017). Towards a postcolonial and decolonising educational administration history. Journal of Educational Administration and History, 49(4), 264-282.

Sergiovanni, T. J. (1991). The principalship: A reflective practice perspective. Publication Sales, Allyn and Bacon.

Şimşek, H. (1997). Pozitivizm ötesi paradigmatik dönüşüm ve eğitim yönetiminde kuram ve uygulamada yeni yaklaşımlar. Kuram ve Uygulamada Eğitim Yönetimi, 3(1), 97-109.

Şişman, M. (1998). Eğitim yönetiminde kuram ve araştırmada alternatif paradigma ve yaklaşımlar. Kuram ve Uygulamada Eğitim Yönetimi, 3(16), 395-422.

Thrupp, M., \& Willmott, R. (2003). Educational management in managerialist times. UK: McGraw-Hill Education

Turan, S. (2004). Modernite ve postmodernite arasında bir insan bilimi olarak Eğitim yönetimi. Akdeniz Üniversitesi Eğitim Fakültesi Dergisi 1(1), 1-8.

Waite, D. (2002). The paradigm wars in educational administration: an attempt at transcendence. International Studies in Educational Administration, 30(1), 66-81.

Watkins, D. (1983). Scientific management and critical theory in education administration. In R. Bates (Ed.), Education administration and the management of knowledge (pp. 119-135). Victoria, Australia: Deakin University.

Willower, D. J. (1983). Evolution in the professorship: past, philosophy, future. Educational Administration Quarterly, 19(3), 179-200.

Yılmaz, K. (2018). Türkiye'deki eğitim yönetimi alanı ile ilgili çalışmalara eleştirel bir bakış. Journal of Human Sciences, 15(1), 123-154.

Yükseköğretim Kurulu [YÖK]. (2019). Öğrenci ve öğretim elemani istatistikleri. 19.06.2019 tarihinde https://www.istatistik.yok.gov.tr adresinden erişim sağlanmıştır. 